\title{
TERMELÉS MAGYARORSZÁGON EURÓPAI ÖSSZEHASONLÍTÁSBAN
}

A magyar gazdaság nyitott gazdaság. Ezért a magyarországi vállalatok teljesítményének, versenyképességének elemzése nem nélkülözhet némi nemzetközi kitekintést. Ez a tanulmány azzal a céllal született, hogy nemzetközi mércével mérve lássuk, hol tartanak ma a magyar feldolgozóipari vállalatok a termelés területén. $E$ cél érdekében a szerzố két szálon indult el. Elemzése elsố felében a világszínvonalú termelés kérdésköréhez köti a versenyképesség-kutatás termelési részét, azt vizsgálva, hogy a versenyképesség-kutatásba bevont vállalati körnek az összetétele a termelés terén alkalmazott gyakorlatok és elért teljesítmények alapján mennyire felel meg egy tíz évvel ezelôtt európai szinten végzett vállalati szintú kutatás eredményeinek. Az elemzés második felében egy 2000-2001-ben lezajlott nemzetközi felmérés európai adataival veti össze a versenyképesség-kutatás adatait. Az eredmények alapján ma még sok hazánkban az olyan vállalat, amelynek pénzügyi teljesítménye nem áll szilárd termelési alapokon. A veszélyeztetett vállalati körbe elsósorban a kis- és közepes méretú, magyar tulajdonban lévố vállalatok tartoznak.

A magyar gazdaság nyitottsága miatt a magyarországi vállalatok teljesítményének, versenyképességének elemzése nem nélkülözhet némi nemzetközi kitekintést. Még inkább alátámasztja ezt Magyarország európai uniós csatlakozása. Ma már kevés olyan vállalat létezik Magyarországon, ahova nem érkezett el valamilyen módon a globalizáció szele.

Magyarországon 1996 óta folytatunk a „Versenyben a világgal" kutatás (továbbiakban Versenyképességkutatás) keretében empirikus információgyújtést annak érdekében, hogy nyomon követhessük a magyar gazdaságban zajló változásokat. Az információgyuujtés fő elemét képező kérdőíves felmérések óriási előnye, hogy viszonylag nagy vállalati kört ölelnek fel (kb. 300 vállalat) a gazdaság minden szektorából, és rengeteg kérdést tartalmaz, ezért valóban hiteles és átfogó képet ad az egész magyar gazdaságról (ld. Chikán és tsai, 1996; Chikán és tsai, 1999; Czakó és tsai, 2004). A felmérés hátránya azonban, hogy a nemzetközi versenyképességre csak közvetett következtetéseket lehet levonni.

Ez a tanulmány azzal a céllal született, hogy nemzetközi mércével mérve lássuk, hol tartanak ma a magyar vállalatok a termelés területén. Az elemzésekhez három kutatásra támaszkodtunk. Elsôsorban a Versenyképesség-kutatás 2004-ben lezajlott 3. fordulójának adatait használtuk fel, hiszen fó célunk a magyar eredmények nemzetközi mércével való vizsgálata. Másodikként egy nemzetközi felmérés végsố eredményeit használjuk fel, hogy láthassuk, a világszínvonalhoz képest mire képesek ma a magyar vállalatok. Ezenkívül egy nemzetközi, termelési stratégiára irányuló felmérésre építünk. A tanulmány két szálon fut.

1. Az elemzés elsố felében a világszínvonalú termelés kérdésköréhez kötjük a versenyképesség-kutatás termelési részét, és azt is megnézzük, hogy a vállalatok fô jellemző́i milyen mértékben befolyásolják a termelési színvonalat.

2. Elemzésünk második felében a termelési stratégiára irányuló nemzetközi felmérés adataival vetjük össze a versenyképesség-kutatás adatait, és részletesebben megvizsgáljuk, milyen termelési célokat túznek a vállalatok maguk elé, milyen menedzsmentprogramokat és technológiákat használnak, és milyen teljesítménymutatók terén hogyan teljesítenek az európai mezőnyhöz képest.

\section{Világszínvonalú termelés: a feldolgozóipari vállalatok rangsorolása}

A'80-'90-esévekbensokkutatófoglalkozottazzalakérdéssel,hogymilyenjellemzókkelírhatóleavilágszínvonalú termelés. Legelőször Hayes-Wheelwright (1984) 
használta a fogalmat, amit késóbb kicsit más értelmezésben Schonberger (1986) és Giffi et al. (1990) is átvett.

A szakirodalom alapján a termelési gyakorlat szintjét meghatározó tényezók a következők (zárójelben az elsô szakirodalmi előfordulás helye áll, de az egyes tényezók több hivatkozott cikkben is előfordulnak):

- A munkaeró ismereteinek növelése, folyamatos képzés (Hayes-Wheelwright, 1984). Ide tartozik a gyakornoki rendszerek kiépítése, iskolákkal tartott kapcsolatok ápolása, a munkaerő ösztönzése és motiválása, a tudás támogatása és mérése, a keresztképzés és rotáció használata stb.

- A munkaeró bevonása, feladatok delegálása (HayesWheelwright, 1984). Elsősorban a menedzsment és a dolgozók közötti korlátok leépítését, a munkások döntési jogkörének növelését takarja.

- Agyártási technológia folyamatos fejlesztése (HayesWheelwright, 1984). A gépek folyamatos, házon belüli, vagy legalábbis a szállítóval szoros kapcsolatban való fejlesztéséról, a technológia és a hozzá szükséges szoft ismeretek egyensúlyban tartásáról szól.

- Fogyasztóközpontúság, minóségmenedzsment (HayesWheelwright, 1984). A minőséget, annak szintjét a fogyasztói elvárásoknak kell meghatároznia, és törekedni kell ennek a szintnek a folyamatos elérésére minden dolgozó bevonásával.

- Folyamatfókusz (Flynn et al., 1999). Ez a szempont már a '90-es évek terméke, amikor a veszteségek kiküszöbölésére való törekvés, illetve az átfutási idôk radikális csökkentésének fogyasztói elvárása kikényszerítette a vállalatokból a folyamatok átgondolását.

- JIT kulcselemei (húzásos rendszer, átállítási idô csökkentése) (Flynn et al., 1999). A JIT-rendszer egészen új alapokra helyezte a termelési rendszereket. Részben ennek terméke a folyamatfókusz is, ami azonban a JIT-tól függetlenül is versenyképességet növelő tényezővé vált. A JIT kulcselemei közé elsősorban a készletcsökkentést célzó, fogyasztói igényekből kiinduló húzásos rendszer és az átállítási idô csökkentése sorolható.

- Gyártási rendszer (Voss-Blackmon, 1996 és Collins et al., 1996). Ezt a dimenziót a „Made in Europe”, (továbbiakban MIE, részletesen ld. késóbb) kutatás nem részletezte, csak felsorolásszerúen tartalmazta. Valószínúleg a korábbiakban már felsorolt tényezók, például a gyártási technológia korszerúsége, összehangoltsága, a gyártás szervezési kérdései sorolhatók ide.

- Logisztika (Voss-Blackmon, 1996 és Collins et al., 1996). Hasonlóan a korábbi szemponthoz ezt a dimenziót is a MIE-kutatás említi, részletezés nélkül.
Mindenesetre ezzel a tényezővel a kutatók már jelzik, hogy a termelés egy anyagáramlási rendszer része, attól nem tud függetlenül múködni és jól teljesíteni.

- Párhuzamos fejlesztés (Voss-Blackmon, 1996 és Collins et al., 1996). A párhuzamos fejlesztés megint a termelés nyitását jelzi az innováció felé. A termékélettartamok rövidülésével a termékek gyors termelésbe vétele és felfuttatása kritikus tényező a vállalatok jövedelmezőségében.

A felsorolt tényezók a termelési színvonal vizsgálatát középpontba helyezố kutatásokban merültek fel. Látható, hogy a legfrissebb ilyen irányú hivatkozás is az előzó évszázad terméke. Az azóta eltelt időben, az ellátásilánc-menedzsment előretörésével egyre többen hangsúlyozzák a vállalaton belüli és azok közötti integráció szerepét a versenyképesség elérésében (Ballou et al., 2000; Narasimhan-Kim, 2001; Senter-Flynn, 1999; Scannel et al., 2000; Vickery et al., 2003; Rosenzweig et al., 2003; Frohlich-Westbrook, 2001). Ezért meglátásunk szerint ma már a termelés sem tekinthetô önmagában, külvilágtól elzárt, illetve más funkcionális területek szürójén keresztül információkhoz jutó funkcióként (Chase-Aquilano, 1985), amint ez már részben a MIE-kutatásokban is megjelenik. Sokkal inkább intenzív együttmúködésre kell törekedni. A termelésben ez elsôsorban a) az információs rendszerek összekapcsolásában, azaz az információáramlás felgyorsulásában és a tervezési rendszerek megosztásában nyilvánul meg, valamint b) a vállalati tevékenységek letisztulásában, és ezzel párhuzamosan a kiszervezés egyre gyakoribb megjelenésében érhetố tetten.

Látható, hogy a megfelelő termelési gyakorlat kiválasztásakor a kutatók azt vizsgálják, hogy melyik milyen mértékben járul hozzá a versenyképesség növeléséhez. A világszínvonalú gyakorlat kritériuma tehát az, hogy a megfelelő termelési gyakorlatot használva a vállalat magasabb teljesítményt érjen el. Mérésekor tehát a gyakorlat használatát és az elért teljesítményt kell figyelembe venni.

\section{A „Made in Europe” (MIE) kutatás}

Vizsgálatunk szempontjából a leglényegesebb eredményeket az IBM szervezésében lezajlott, a termelés európai színvonalának meghatározására szervezett MIE-kutatás tartalmazza, ezekkel fogjuk a magyar eredményeket összevetni (Collins et al., 1996; Flynn et al., 1999; Prabhu et al., 2000; Voss et al., 1995; VossBlackmon, 1996). A MIE-kutatásban alkalmazott modell szerint a jó termelési gyakorlat vezet a jó termelési teljesítményhez, és ezek eredôje a jó üzleti teljesítmény. A termelési gyakorlat megragadásakor a MIE-kutatás

\section{VEZETÉSTUDOMÁNY}


nagyban épített a korábbi, fent is említett munkákra, a termelésmenedzsment eszköztárának széles skáláját alkalmazva annak mérésére. A termelési teljesítmény operacionalizálásakor a termelési szakirodalomban jól ismert versenyelőny-forrásokat (termelési költség, minőség, szállítási megbízhatóság és idő, rugalmasság) fogták meg mutatókkal. A MIE-kutatás objektív és szubjektív mutatókat egyaránt használt. A számszerú értékeket üzemlátogatásokkal „hitelesítették”.

A MIE-kutatásban a vállalatok termelési gyakorlatukra és termelési teljesítményükre 100-100 pontot kaphattak. E pontok alapján a vállalatokat hat csoportba sorolták az 1. ábra szerint.

1. ábra

\section{A világszínvonal-mérés skálái}

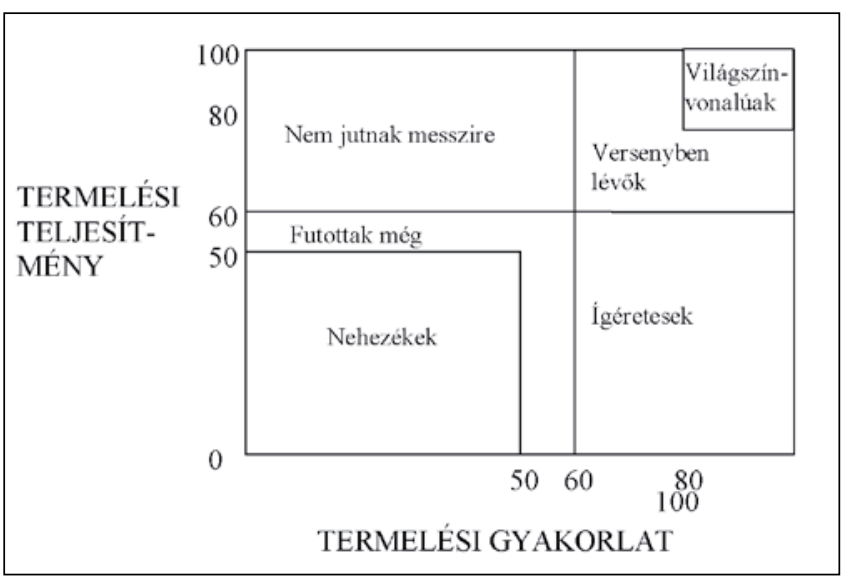

Forrás: Voss et al., 1995

A kutatás Európából 663 feldolgozóipari vállalat adatait használta fel. Európára és ezen belül néhány országra az 1. táblázatban szereplő eredményeket hozta.

A továbbiakban megvizsgáljuk, hogy a Versenyképesség-kutatás alapján hogyan ragadható meg a termelési gyakorlat és teljesítmény.

\section{A világszínvonal mérése a Versenyképesség-kutatás alapján}

A termelési színvonal alapján létrehozandó csoportok kialakítását a nemzetközi kutatásoknak megfelelóen a termelési gyakorlat és a termelési teljesítmény köré építjük fel. Bár a versenyképesség-adatbázisban szolgáltató, mezőgazdasági, kitermelóipari vállalatok is szerepelnek, ezek termelés szempontból jelentôsen különböznek a feldolgozóipari vállalatoktól, ráadásul a MIE-kutatás is csak a feldolgozóiparra terjedt ki. Ezért elemzésünket a versenyképesség-felmérés 154 feldolgozóipari vállalatára végezzük el.
1. táblázat

A termelés szintjei Európa néhány országában

\begin{tabular}{|l|c|c|c|c|c|}
\hline & $\begin{array}{c}\text { Finn- } \\
\text { ország }\end{array}$ & $\begin{array}{c}\text { Né- } \\
\text { met- } \\
\text { ország }\end{array}$ & $\begin{array}{c}\text { Nagy- } \\
\text { Britan- } \\
\text { nia }\end{array}$ & $\begin{array}{c}\text { Hol- } \\
\text { landia }\end{array}$ & Európa \\
\hline $\begin{array}{l}\text { Világszínvona- } \\
\text { lúak (kiváló/ki- } \\
\text { váló) }\end{array}$ & $0,0 \%$ & $2,9 \%$ & $2,3 \%$ & $1,0 \%$ & $2,8 \%$ \\
\hline $\begin{array}{l}\text { Versenyben } \\
\text { lévók (jó/jó vagy } \\
\text { egyik kiváló) }\end{array}$ & $34,8 \%$ & $53,3 \%$ & $40,3 \%$ & $48,0 \%$ & $52,2 \%$ \\
\hline $\begin{array}{l}\text { Igéretesek (gya- } \\
\text { korlat legalább } \\
\text { jó, teljesítmény } \\
\text { legfeljebb köze- } \\
\text { pes) }\end{array}$ & $39,1 \%$ & $16,7 \%$ & $17,7 \%$ & $22,4 \%$ & $16,5 \%$ \\
\hline $\begin{array}{l}\text { Nem jutnak } \\
\text { messzire } \\
\text { (gyakorlat leg- } \\
\text { feljebb közepes, } \\
\text { teljesítmény } \\
\text { legalább jó) }\end{array}$ & $4,3 \%$ & $8,6 \%$ & $9,5 \%$ & $11,2 \%$ & $9,0 \%$ \\
\hline $\begin{array}{l}\text { Futottak még } \\
\text { közepes/köze- } \\
\text { pes vagy egyik } \\
\text { gyenge) }\end{array}$ & $21,7 \%$ & $17,6 \%$ & $22,6 \%$ & $16,3 \%$ & $16,5 \%$ \\
\hline $\begin{array}{l}\text { Nehezékek } \\
\text { (gyenge/gyenge) }\end{array}$ & $0,0 \%$ & $1,0 \%$ & $7,5 \%$ & $1,0 \%$ & $3,0 \%$ \\
\hline
\end{tabular}

Forrás: Voss et al., 1995

\section{Termelési gyakorlat}

A világszínvonalú termelési gyakorlat megragadásához azt a változócsoportot használjuk fel a Versenyképesség-kutatás 2004 kérdőívból, amely az egyes termelési programok használatát firtatja, igen-nem értékekkel ragadva meg a használat tényét. A fenti cikkek alapján az alábbi változókat vontuk be - a megjelenés sorrendjében - az elemzésbe:

- információs és kommunikációs technológiák és/vagy ERP szoftver bevezetése: ez a dimenzió nem szerepelt a WCM jellemzói között (bár a Voss-Blackmon, 1996 kutatásban a gyártási rendszernek ez nagy valószínúséggel részét képezi), a vállalaton belüli integrációnak - ezen belül a tervezés megerôsítésének és az információáramlás felgyorsításának - versenyképességre gyakorolt pozitív hatását több irodalmi forrás is alátámasztja (Ballou et al., 2000; NarasimhanKim, 2001),

- az ellátási stratégia újragondolása és rendszerezése az ellátási portfólió megszervezése és menedzsmentje: ez a jellemző leginkább Voss-Blackmon (1996) 
logisztika pontjához kapcsolható. Integrálni kell az egyes vállalatok tervezési és információs rendszereit, együtt kell múködni a partnerekkel a termékfejlesztés és bevezetés terén, össze kell hangolni a vállalatok közötti anyagáramlási, pénzügyi, információs folyamatokat, amiben értelemszerúen a termelésnek is aktív szerepet kell játszania. (Senter-Flynn, 1999; Scannel et al., 2000; Vickery et al., 2003; Rosenzweig et al. 2003; Frohlich-Westbrook, 2001),

- koncentrálás az alaptevékenységekre, támogató folyamatok és tevékenységek outsourcingja (pl. készletgazdálkodás, karbantartás, anyagkezelés):. a gyártani vagy vásárolni kérdés meghatározása, a vertikális integráció megfelelő szintjének növelése ma a versenyképesség egyik fơ forrása, és e kérdés eldöntésében a termelés is aktív szerepet játszik, a logisztika folyamatfókusz ponthoz kapcsolható szempont,

- gyártási/szolgáltatási folyamatok és berendezések átstrukturálása a folyamatfókusz és áramvonalasitás érdekében (pl. sejtszerú elrendezés) - folyamatfókuszhoz kapcsolható szempont,

- minốségjavítási és ellenórzési programok (pl. TQM, szigma projektek, minôségi körök) - minőségmenedzsmenthez kapcsolható szempont,

- delegáció szintjének növelése és a munkaeró tudásszintjének növelése érdekében inditott programok (pl. felhatalmazás, képzés, fejlesztő- vagy autonóm csoportok),

- gyártóberendezések modernizálása az iparági standardot eléró vagy azt meghaladó szintre - a gyártási technológiához és a gyártási rendszerhez kapcsolható szempont,

- programok a gyártási folyamatok automatizálására - a gyártási technológiához és a gyártási rendszerhez kapcsolható szempont,

- programok a húzásos termelés bevezetésére (pl. sorozatnagyság és átállítási idő csökkentése, kanban rendszerek használata stb.) - JIT kulcselemeihez kapcsolható szempont,.

- programok a gépek termelékenységének fokozására (pl. TPM programok) - minóségmenedzsmenthez és a gyártási technológiához kapcsolható szempont.

A fenti tíz szempontra adott 0-1 értékeket összegeztük. Prabhu et al. (2000) és Collins et al. (1996) alapján a kialakult, 0-10 közötti értéktartományban mozgó indexre kategóriákat alakítottunk ki. Mivel mindkét cikkben (ahol 0-100 között lehetett az index) a kategóriák 0$50,50-60,60-80$ és 80 felett voltak, ezért mi is hasonló elvet követtünk, és a következő kategóriákat határoztuk meg: gyenge 0-4, közepes 5-6, jó 7, kiváló 8-10. A határok megállapításánál nehézséget okozott, hogy a bináris alapváltozók eredményeként kialakult skála csak egész számokon mozgott. Az eredeti kategóriák által kijelölt határértékeknél a megoszlás alapján húztunk vonalat. Például, a gyenge sáv lehetett volna a 0-5 is, de mivel a 0-4 sávba is nagyon sok vállalat tartozott, ezért az 5 értéket már a következố kategóriába tettük. Mivel ez a kategória a középmezóny, ezért inkább ezt a sávot hagytuk szélesebbre (5-6), a jót kisebbre (7). A legjobb kategória 8-tól kezdôdik.

\section{Termelési teljesítmény}

Ezt a szempontot a kérdőívból a termelési teljesítményváltozásra vonatkozó kérdéscsoport 1-5 skálán mért egyes elemeinek használatával ragadtuk meg. (Hogyan változott a teljesítménye az egyes dimenziók mentén az elmúlt három évben?)

Mivel a termelési teljesítményváltozás 17 változója az egyes versenyelőnyökre különböző mértékben kérdez rá (pl. a rugalmasságra négy kérdés, a megbízhatóságra mindössze egy szerepel), ezért a kérdések súlyozásával, összevonásával az egyes versenyelőnyforrásokat azonos súllyal figyelembe vevő csoportosítást alakítottunk ki. Például a rugalmasság négy változóját összevontuk és a vállalatokra egyenként átlagoltuk. Ezek az átlagok mutatják, hogy rugalmasság terén a vállalatok milyen mértékben fejlődtek. Ugyanezt elvégeztük a költség, a minőség, a megbízhatóság és az idô terén elért teljesítményváltozásokra. A termelési technológia átlagos korát nem soroltuk be sehová, kihagytuk az elemzésból. Az öt képzett változóból kialakítható index terjedelme 5-25 között van, viszont nem csak egész értékeket vehet fel. A megállapított határok a MIE értékeinek megfelelően: gyenge teljesítmény 5-12,5; közepes 12,51-15, jó 15,01-20, kiváló 20,01 felett (minden értéket 4-gyel szorozva jutunk el a MIE-ponthatárokhoz). A csoportosítást a 2. táblázat tartalmazza.

Ezután Cronbach-alfa segítségével megvizsgáltuk, hogy az alapváltozókból kialakított konstrukciók menynyire megbízhatóan írják le az adott jelenséget. Ennek eredményeit is tartalmazza a táblázat. Nem volt olyan konstrukció, ahol egy-egy változó elhagyásával javult volna a konstrukció értéke. Mindegyik alfa-érték meghaladja a $60 \%$-os, szakirodalomban elvárt szintet.

A konstrukciókat ezek után úgy alakítottuk ki, hogy a hozzájuk tartozó változók átlagát tekintettük a konstrukció értékének.

Az eljárás eredményeként a termelési gyakorlat indexe és a teljesítményváltozási index közötti korreláció szintje 0,270, ami 0,2\%-os szinten szignifikáns kapcsolatot jelez. Más szavakkal, a felhasznált termelésme-

\section{VEZETÉSTUDOMÁNY}


A teljesítményváltozás mutatóinak csoportosítása és a csoportok fő statisztikai jellemzôi

\begin{tabular}{|c|c|c|c|c|c|}
\hline & Költség & Minôség & Megbízhatóság & Idő & Rugalmasság \\
\hline $\begin{array}{c}\text { Eredeti } \\
\text { változók }\end{array}$ & $\begin{array}{l}\text { Termelékenység } \\
\text { Közvetlen } \\
\text { munkaráfordítás } \\
\text { Kapacitáskihasználás } \\
\text { Készletforgás } \\
\text { Termelési } \\
\text { egységköltség }\end{array}$ & $\begin{array}{l}\text { Fogyasztó által } \\
\text { észlelt minőség } \\
\text { Vevőszolgálat } \\
\text { Garanciális költség } \\
\text { Géphiba miatti } \\
\text { leállási idő }\end{array}$ & $\begin{array}{l}\text { Rendelésteljesítés } \\
\text { pontossága }\end{array}$ & $\begin{array}{l}\text { Rendelésteljesítési } \\
\text { idő } \\
\text { Vevői reklamáció } \\
\text { kezelési ideje } \\
\text { Termelési átfutási } \\
\text { idő }\end{array}$ & $\begin{array}{l}\text { Legyártható } \\
\text { termékfajták száma } \\
\text { Új termék } \\
\text { bevezetésének } \\
\text { időigénye } \\
\text { Gépátállítási idő }\end{array}$ \\
\hline $\begin{array}{c}\text { Cronbach- } \\
\text { alfa }\end{array}$ & 0,79 & 0,68 & - & 0,71 & 0,65 \\
\hline Összátlag & 3,39 & 3,37 & 3,70 & 3,59 & 3,40 \\
\hline
\end{tabular}

nedzsment-eszközök számossága, és a teljesítmények változása között összefüggés van. A termelési gyakorsával kialakult kereszttábla a 3. táblázatban látható. lat és az új termelési teljesítmény-mutató felhasználá-

Ha ez így van, akkor még van remény, hogy a termelési gyakorlat javításához szükséges pénzügyi erôforrásokat elôteremtsék.

Talán már az összehasonlítás módszertanából is kiderült, hogy nem teljesen ugyanazokkal a változókkal történt az összevetés. A termelési

A termelési teljesítmény-változás (T1) és a termelési gyakorlat kereszttáblája

\begin{tabular}{|l|l|c|c|c|c|c|}
\hline & & \multicolumn{5}{|c|}{ Termelési teljesítmény indexe } \\
\hline & & Gyenge & $\begin{array}{c}\text { Köze- } \\
\text { pes }\end{array}$ & Jó & Kiváló & $\begin{array}{c}\text { Össze- } \\
\text { sen }\end{array}$ \\
\hline \multirow{4}{*}{$\begin{array}{l}\text { Termelési } \\
\text { gyakorlat } \\
\text { indexe }\end{array}$} & Gyenge & 2 & 17 & 41 & 8 & 68 \\
\cline { 2 - 7 } & Közepes & 2 & 2 & 17 & 5 & 26 \\
\cline { 2 - 7 } & Jó & 0 & 2 & 9 & 4 & 15 \\
\cline { 2 - 7 } & Kiváló & 0 & 3 & 12 & 7 & 22 \\
\cline { 2 - 7 } & Összesen & 4 & 24 & 79 & 24 & 131 \\
\hline
\end{tabular}
gyakorlat bináris jellege sokkal szigorúbban elhatárolja egymástól a használatot és nem használatot, mint egy 1-5 Likert-skála, ami rosszabb színben tüntetheti fel a magyar gyakorlatot. Ráadásul a termelési teljesítményeknek sem az abszolút értékét, hanem a változás mértékét tettuik vizsgálat tárgyává. ${ }^{1}$ Az eredményeket tehát fenntartásokkal kell kezelnünk.

$\mathrm{Az}$ egyes termelési-színvonal csoportok mögötti tényezók feltárásához a termelési gyakorlat és a termelési teljesítmény alapján három csoportot hoztunk létre. A jó vállalatok sorába
A módszer előnye, hogy ha az eredeti változók közül egy-egy hiányzott, a többi átlaga révén még az adott vállalat benne maradt az elemzésben, így 131 vállalatot tudtunk a 154ból besorolni. A 3. táblázat színezése már mutatja az egyes kategóriákat. Az európai eredményekkel való összevetést a 4. táblázat tartalmazza.

Az eredmények alapján a magyar vállalati szektor termelési gyakorlata még jócskán le van szakadva az európai színvonaltól. Némileg talán biztató, hogy a lemaradtak nagy része még képes jó termelési teljesítménnyel palástolni gyenge termelési gyakorlatát - legalábbis a termelésvezetốk szubjektív véleménye szerint -, és remélhetóleg ez a pénzügyi eredményességet is pozitívan befolyásolja.
4. táblázat

A magyarországi termelési színvonal (gyakorlat és teljesítményváltozás csoportosított mutatókkal) Európával összevetve

\begin{tabular}{|l|c|c|}
\hline & $\begin{array}{c}\text { Magyar- } \\
\text { ország }\end{array}$ & Európa \\
\hline 1. Világszínvonalúak (kiváló/kiváló) & $5,4 \%$ & $2,8 \%$ \\
\hline $\begin{array}{c}\text { 2. Versenyben lévók (jó/jó vagy egyik } \\
\text { kiváló) }\end{array}$ & $19,1 \%$ & $52,2 \%$ \\
\hline $\begin{array}{c}\text { 3. Ígéretesek (gyakorlat legalább jó, } \\
\text { teljesítmény legfeljebb közepes) }\end{array}$ & $3,8 \%$ & $16,5 \%$ \\
\hline $\begin{array}{l}\text { 4. Nem jutnak messzire (gyakorlat legfel- } \\
\text { jebb közepes, teljesítmény legalább jó) }\end{array}$ & $54,2 \%$ & $9,0 \%$ \\
\hline $\begin{array}{c}\text { 5. Futottak még (közepes/közepes vagy } \\
\text { egyik gyenge) }\end{array}$ & $16,0 \%$ & $16,5 \%$ \\
\hline 6. Nehezékek (gyenge/gyenge) & $1,5 \%$ & $3,0 \%$ \\
\hline
\end{tabular}


a világszínvonalú és a versenyben lévô vállalatokat soroltuk (32 vállalat, 24,5\%), a gyenge vállalatok sorába a futottak még és a nehezékek kategóriák vállalatait (23 vállalat, 17,5\%), és végül a közepesek sorába az ígéretesek és a nem jutnak messzire csoportjait tettük (76 vállalat, 58\%). E három csoportot használtuk a további elemzésekhez.

\section{A termelési színvonal kapcsolata néhány fó jellemzóvel}

A versenyképesség-kutatásban kialakítottunk néhány vállalati csoportot a fố jellemzók mentén (Wimmer-Csesznák, 2005), úgy mint a) vállalati méret (kis-, közepes, nagyvállalat), b) tulajdonos kiléte (többségi állami, többségi belföldi, többségi külföldi), c) vállalati teljesítmény (vezetók, átlagosak, lemaradók), d) iparág (élelmiszeripar, vegyipar, könnyúipar, gépipar, egyéb), e) diverzifikáltság foka (egy üzletág, diverzifikált, erôsen diverzifikált), f) exportorientáció mértéke (6 kategória a nincs exporttól a dominánsig), g) piaci koncentráció foka (koncentrált, mérsékelten koncentrált, megosztott), h) változásokhoz való viszony (nehezen követők, késve reagálók, felkészülő́k, befolyásolók), i) EU-várakozások (optimisták, semlegesek, nehézségre számítók), j) piaci célok (pozíció-megtartás, mérsékelt növekedés, agresszív növekedés).

A vállalati csoportok között szignifikáns különbséget a méret, a tulajdonos és a vállalati teljesítmény alapján találtunk, a továbbiakban ezeket részletezzük.

A termelési színvonal alapján kialakított három csoport a vállalatmérettel szignifikáns kapcsolatot mutat (Chi-négyzet: 18,9, p-érték: 0,001). A nagyvállalatok

\section{A termelési színvonal és a vállalatméret összefüggései}

\begin{tabular}{|c|c|c|c|c|c|}
\hline \multicolumn{6}{|c|}{ Vállalati méret } \\
\hline \multirow{4}{*}{$\begin{array}{c}\text { Termelési } \\
\text { színvonal }\end{array}$} & $\begin{array}{c}\text { Kisvál- } \\
\text { lalat }\end{array}$ & $\begin{array}{c}\text { Közepes } \\
\text { vállalat }\end{array}$ & $\begin{array}{c}\text { Nagyvál- } \\
\text { lalat }\end{array}$ & Összesen \\
\cline { 2 - 6 } & Közenes & $\begin{array}{c}8 \\
(22,3 \%)\end{array}$ & $\begin{array}{c}11 \\
(22,5 \%)\end{array}$ & $\begin{array}{c}4 \\
(8,6 \%)\end{array}$ & 23 \\
\cline { 2 - 6 } & Jó & $\begin{array}{c}25 \\
(69,4 \%)\end{array}$ & $\begin{array}{c}30 \\
(61,2 \%)\end{array}$ & $\begin{array}{c}21 \\
(45,7 \%)\end{array}$ & 76 \\
\cline { 2 - 6 } & Összesen & $\begin{array}{c}36 \\
(100 \%)\end{array}$ & $\begin{array}{c}21 \\
(16,3)\end{array}$ & 32 \\
$(45,7 \%)$ & $\begin{array}{c}46 \\
(100 \%)\end{array}$ & 131 \\
\hline
\end{tabular}

5. táblázat

A termelési színvonal és a tulajdonosi struktúra összefüggései

\section{Tulajdonos}

\begin{tabular}{|c|c|c|c|c|c|}
\hline & & $\begin{array}{c}\text { Többségi } \\
\text { állami }\end{array}$ & $\begin{array}{c}\text { Többségi } \\
\text { belföldi }\end{array}$ & $\begin{array}{c}\text { Többségi } \\
\text { külföldi }\end{array}$ & Összesen \\
\cline { 2 - 6 } & Gyenge & $\begin{array}{c}4 \\
(20,0 \%\end{array}$ & $\begin{array}{c}12 \\
(17,4 \%)\end{array}$ & $\begin{array}{c}5 \\
(13,9 \%)\end{array}$ & 21 \\
\cline { 2 - 6 } Közepes & $\begin{array}{c}11 \\
(55,0 \%)\end{array}$ & $\begin{array}{c}47 \\
(68,1 \%)\end{array}$ & $\begin{array}{c}16 \\
(44,4 \%)\end{array}$ & 74 \\
\cline { 2 - 6 } & Jó & $\begin{array}{c}5 \\
(25,0 \%)\end{array}$ & $\begin{array}{c}10 \\
(14,5 \%)\end{array}$ & $\begin{array}{c}15 \\
(41,7 \%)\end{array}$ & 30 \\
\cline { 2 - 6 } & Összesen & $\begin{array}{c}20 \\
(100 \%)\end{array}$ & $\begin{array}{c}69 \\
(100 \%)\end{array}$ & $\begin{array}{c}36 \\
(100 \%)\end{array}$ & 125 \\
\hline
\end{tabular}

csaknem felére jellemző, hogy magas termelési színvonalon dolgoznak, a kis- és közepes vállalatoknál jóval kisebb ez az arány (5. táblázat). A különbség oka lehet a nagyobbak jobb tókeellátottsága, könnyebb hitelfelvétele, melyek révén a termelési gyakorlat megújítására, a munkaerő és a technológia fejlesztésére több forrás jut. Ráadásul egy ugyanolyan beruházás egy kisvállalat esetében arányában nagyobb megterhelést jelent, mint egy nagyvállalatnál. Valószínúleg a nagyobb létszámú munkaeró is több rugalmasságot biztosít, könnyebb a továbbképzésre járó alkalmazott helyettesítése.

Nem ilyen nagyok, de azért szignifikánsak a különbségek a tulajdonosokat vizsgálva (Chi-négyzet: 9,9, p-érték: 0,042). A legelónyösebbnek a külföldi tulajdonos bizonyult (6. táblázat). Érdekes módon a többségi állami tulajdonban lévố vállalatok közül arányaiban több a jó termelési színvonalon múködő vállalat, mint a belföldi tulajdonosok között. A különbségek oka részben hasonló lehet a vállalati méret esetén felsoroltakhoz: a külföldi tulajdonos által hozott tốke, és az állami háttér által biztosított többségi állami tulajdon jobb lehetôségeket biztosít a vállalatoknak, mint a hitelproblémákkal múködő többségi belföldi tulajdonossal rendelkezô vállalatok.

Van még különbség a vállalati teljesítményben (Chi-négyzet: 9,32, p-érték: 0,054). A gyenge vállalati teljesítménnyel rendelkezó vállalatok termelési színvonala is inkább a gyenge kategóriába sorolható, a vállalati teljesítmény szerint vezetô vállalatok termelési teljesítménye is nagyobb valószínúséggel tartozik a jó kategóriába (7. táblázat). Az összefüggés azonban viszonylag gyenge, mint ahogy erre a szignifikancia-szint is utal.

\section{VEZETÉSTUDOMÁNY}


A termelési színvonal és a vállalati teljesítmény összefüggései

\begin{tabular}{|c|c|c|c|c|c|}
\hline \multicolumn{7}{|c|}{ Vállalati teljesítmény } \\
\hline & & $\begin{array}{c}\text { Lemara- } \\
\text { dók }\end{array}$ & $\begin{array}{c}\text { Átlagosan } \\
\text { teljesítók }\end{array}$ & Vezetók & Összesen \\
\hline \multirow{4}{*}{$\begin{array}{c}\text { Termelési } \\
\text { színvonal }\end{array}$} & Gyenge & $8(23,5 \%)$ & $7(15,9 \%)$ & $6(12,8)$ & 21 \\
\cline { 2 - 6 } & Közepes & $\begin{array}{c}23 \\
(67,6 \%)\end{array}$ & $\begin{array}{c}26 \\
(59,1 \%)\end{array}$ & $\begin{array}{c}23 \\
(48,9 \%)\end{array}$ & 72 \\
\cline { 2 - 6 } & Jó & $3(8,9 \%)$ & $11(25 \%)$ & $18(38,3)$ & 32 \\
\cline { 2 - 6 } & Összesen & $\begin{array}{c}34 \\
(100 \%)\end{array}$ & $\begin{array}{c}44 \\
(100 \%)\end{array}$ & $\begin{array}{c}47 \\
(100 \%)\end{array}$ & 125 \\
\hline
\end{tabular}

A Versenyképesség-kutatás adatbázisát is leszúkítettük a fémfeldolgozó iparra és a gépiparra. Bár elképzelhetô, hogy az egyéb feldolgozóipari vállalati csoport is tartalmaz hasznosítható adatokat, ez azonban nem egyértelmú, ezért csak az említett két iparággal foglalkozunk. A Versenyképesség-adatbázisban 17 fémfeldolgozó és 26 gépipari vállalat található, a továbbiakban összevontan kezeljük óket (a táblázatokban VK vállalatok címen szerepelnek).

A 8. táblázat néhány fố szempont szerint hasonlítja össze a vállalatokat. Az összehasonlításból látszik, hogy a Versenyképesség-kutatás mintájában szereplő vállalatok mérete és eredményessége elmarad a nemzetközi mintában is

\section{A magyar vállalatok termelési jellemzói egy nemzetközi felmérés tükrében}

Ebben a részben a Versenyképesség-kutatás mellett egy olyan felmérés adatait használjuk, ami a fémfeldolgozás, gépipar, elektronikai ipar, múszeripar, jármúipar cégeiról rendelkezik kérdőíves adatokkal. ANemzetközi Termelési Stratégia Kutatás(International Manufacturing Strategy Survey, IMSS) felmérése a fenti iparágakban 1992 óta világszerte gyújit a vállalatok termeléssel kapcsolatos helyzetére, gyakorlatára, teljesítményére és jövőbeli elképzeléseire vonatkozó adatokat. A versenyképesség-kérdőív termelési részének összeállításakor erősen támaszkodtunk erre annak érdekében, hogy a nemzetközi kitekintést is minél teljesebb és konzisztensebb módon meg tudjuk tenni.

Az összehasonlító elemzéshez az IMSS-ben 2000ben gyưjiött adatokat vizsgáljuk. Ez a kis időeltolódás véleményünk szerint nem okoz különösebb problémát, fóleg azért nem, mert a korábbi Versenyképesség-kutatás fordulójának eredményei szerint (Demeter, 2001) akkor még volt mit behozniuk a magyar vállalatoknak. Ha mára sikerült volna ezt a nem kis lemaradást behoznunk, az azt jelentené, hogy lemaradásunk csak néhány évre tehetó.

A 2001-es IMSS-felmérésben 474 vállalat vett részt. Mivel Magyarország teljesítóképességét leginkább az EU-kapcsolatok befolyásolják, ezért az adatok homogenitásának növelése érdekében a vizsgálódásokhoz csak az Európai Unió területén található vállalatok eredményeit vettük alapul. A mintában 318 európai vállalat található (a táblázatokban IMSS EU-vállalatok), és rajtuk kívül további 58 magyar vállalat is részt vett a felmérésben (a táblázatokban IMSS HU-vállalatok), e két vállalatcsoport adatait használjuk fel. szereplő magyar vállalatokétól. Az IMSS magyar és EU-adatok között nincs szignifikáns eltérés.

8. táblázat

A vizsgált vállalati csoportok néhány fố jellemzője

\begin{tabular}{|l|c|c|c|}
\hline Jellemzók & $\begin{array}{c}\text { IMSS EU- } \\
\text { vállalatok* }\end{array}$ & $\begin{array}{c}\text { IMSS } \\
\text { magyar } \\
\text { vállalatok* }\end{array}$ & $\begin{array}{c}\text { Verseny- } \\
\text { képesség- } \\
\text { kutatás } \\
\text { vállalatai** }\end{array}$ \\
\hline $\begin{array}{l}\text { Vállalatok } \\
\text { száma }\end{array}$ & 318 & 58 & 43 \\
\hline $\begin{array}{l}\text { Átlagos } \\
\text { vállalatméret }\end{array}$ & 600 fö & 545 fö & 330 fö \\
\hline ROS & $9,6 \%$ & $7,0 \%$ & $4,9 \%$ \\
\hline ROI & $24,8 \%$ & $12,5 \%$ & $4,0 \%$ \\
\hline
\end{tabular}

*2000-es adatok, **2002-es adatok

\section{Termelési célok}

Mind az IMSS, mind a Versenyképesség-kutatás foglalkozott azzal a kérdéssel, hogy a jövőben hogyan alakul majd a vállalatok termelési célrendszere. A cégeknek 1-5 skálán kellett megbecsülniük, hogy az egyes szempontoknak milyen prioritást adnak. A 9. táblázat az eredményeket mutatja.

AzIMSS-adatbázison belüli szignifikancia-vizsgálat azt mutatja, hogy lényeges különbség van a magyar és az EU-vállalatok célstruktúrájában. Míg a magyar vállalatok a költség- és minőség zempontoknak nagyobb hangsúlyt adnak külföldi társaiknál, addig a rugalmassági szempontok (elsôsorban a termékfejlesztési idő és a folyamatszemléletre utaló készletforgás) hátrébb vannak a rangsorban. A két felmérés magyar adatait összevetve nem tûnik nagynak az eltérés. Leginkább a kapacitáskihasználás javítása, a termékváltoztatási képességek javítására való törekvés és a gyorsasági szem- 
9. táblázat

A termelési célok prioritási sorrendje a válaszok átlaga szerint (1 - nem fontos, 5 - rendkívül fontos)

\begin{tabular}{|l|c|c|c|}
\hline \multicolumn{1}{|c|}{ Termelési célok } & $\begin{array}{c}\text { IMSS } \\
\text { Eu }\end{array}$ & $\begin{array}{c}\text { IMSS } \\
\text { Hu }\end{array}$ & VK \\
\hline Gyártási minóség javítása*** & 3,83 & 4,66 & 4,44 \\
\hline $\begin{array}{l}\text { Általános költségek } \\
\text { csökkentése*** }\end{array}$ & 3,88 & 4,32 & 4,48 \\
\hline $\begin{array}{l}\text { Készletforgási idó } \\
\text { csökkentése* }\end{array}$ & 3,84 & 4,11 & 4,05 \\
\hline $\begin{array}{l}\text { Rendelésteljesítés } \\
\text { pontosságának növelése* }\end{array}$ & 4,07 & 4,28 & 4,33 \\
\hline $\begin{array}{l}\text { Rendelésteljesítési idő } \\
\text { csökkentése }\end{array}$ & 3,89 & 3,89 & 4,14 \\
\hline $\begin{array}{l}\text { Munka termelékenységének } \\
\text { növelése*** }\end{array}$ & 4,06 & 4,40 & 4,60 \\
\hline $\begin{array}{l}\text { Kapacitáskihasználás } \\
\text { javítása** }\end{array}$ & 3,59 & 4,03 & 4,37 \\
\hline $\begin{array}{l}\text { Gyártási átfutási idő } \\
\text { csökkentése }\end{array}$ & 3,91 & 3,86 & 4,30 \\
\hline $\begin{array}{l}\text { Termékváltoztatási képesség } \\
\text { javítása }\end{array}$ & 3,32 & 3,52 & 3,98 \\
\hline $\begin{array}{l}\text { Mennyiségváltoztatási képesség } \\
\text { javítása }\end{array}$ & 3,80 & 3,59 & 3,80 \\
\hline $\begin{array}{l}\text { Termékfejlesztési ciklus } \\
\text { rövidítése* }\end{array}$ & 3,94 & 3,63 & 3,76 \\
\hline
\end{tabular}

1 A * szignifikáns különbséget mutat az IMSS-felmérés magyar és európai része között. Az IMSS és a VK-kutatás között nem végeztünk szignifikancia-vizsgálatokat.

${ }^{*} \mathrm{p}<0,1, * * \mathrm{p}<0,05, * * * \mathrm{p}<0,01$

pontok előtérbe kerülése átütő (rendelésteljesítési idő csökkentése, gyártási átfutási idố csökkentése). Fontos azonban észrevenni, hogy a másik mintában lényegesnek titulált szempontok jelentősége sem csökkent. Más szavakkal, ami régen fontos volt, az ma is az, de újabb célok csatlakoztak a régiekhez. Ez a „rangsorolás” különösen a nemzetközi adatokkal összevetve problémás: lehetetlen mindennek ugyanakkora hangsúlyt adni, a vállalatoknak világosabb prioritásokkal kellene rendelkezniük.

A 2. ábra grafikusan is szemlélteti az eredményeket. Az ábrából is látszik, hogy a Versenyképesség-adatok két szemponttól eltekintve mindenhol a legmagasabbak. Ugyanakkor pozitív fejlemény a rugalmassági és idốbeli szempontok erôsödése. Szintén pozitív, hogyha a célok hierarchiáját, rangsorát nézzük, akkor abban sincs lényeges eltérés a külföldi és a magyar vállalatok között, pedig korábban ez egyáltalán nem így volt (Demeter, 1996).
A termelési célok prioritási sorrendje grafikusan

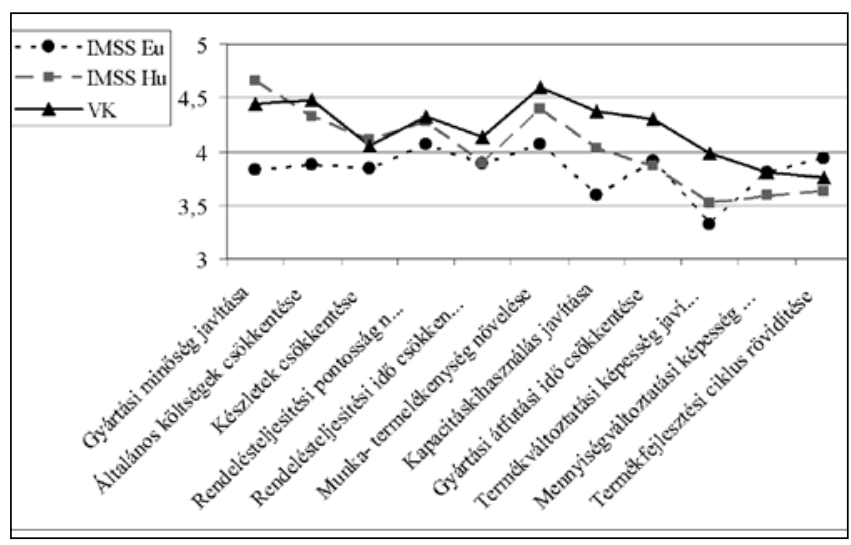

\section{Felhasznált eszközök és technológiák}

A célok után lássuk, hogy mennyit tesznek a vállalatok a célok megvalósulása érdekében. A tárgyalást itt két részre bontjuk. Az elsố részben az ún. akcióprogramokat tárgyaljuk, amelyek a termelésmenedzsment egyes területein megtett lépéseket mutatják. Ezután a termelés technológiáját vizsgáljuk.

Sajnálatos módon a versenyképesség-kérdőívben csak igen/nem választ lehetett adni arra a kérdésre, hogy használják-e az adott programot. Az IMSS-kérdőívben a használat intenzitását kellett 1-5 skálán bejelölni, ahol 1 a nincs használat, 5 a teljes körú használatot jelenti. Az IMSS európai és magyar vállalatai között van néhány szignifikáns különbség, amit vastaggal ki is emeltünk. A felhasznált termelésmenedzsment-eszközökról a 10. táblázat nyújt információt.

A magyar vállalatok - a válaszok szerint - intenzívebben használják az outsourcing és a minőségjavítás eszközeit, ugyanakkor az információ/kommunikációs technológiák és a termékfejlesztés gyorsítását szolgáló eszközök terén határozott lemaradásban vannak a mintában szereplő európai vállalatokhoz képest. Ha összevetjük a kapott eredményeket a termelési célokkal, ahol lehet, akkor konzisztensnek tűnnek, hiszen a minőségjavítást a magyar vállalatok határozottan fontosabb célnak tartották, a termékfejlesztés gyorsítását pedig jóval kevésbé fontosnak, mint az európai vállalatok. Az IT és az outsourcing erósítése számos célhoz tartozhat, ezt ellenőriztük is. Érdekes módon az IT az európai mintában egyedül a termékminőség és megbízhatóság céljával mutatott kapcsolatot (ez a cél a Versenyképességkutatásban nem szerepelt), a magyar mintában 12-vel! Mintha a magyar vállalatok csodaszernek tartanák az IT-t. Persze az is lehet, hogy a differenciálatlan prioritások miatt született ez az eredmény. Némileg hasonló az outsourcing értékelése is. Mindkét vállalatcsoport ese-

\section{VEZETÉSTUDOMÁNY}




\begin{abstract}
3. ábra
A felhasznált termelésmenedzsment-eszközök grafikusan

tében szignifikánsan korrelál az outsourcing a termékminőség és megbízhatóság, a termékmix-rugalmasság, a rendelésteljesítési idő és a környezetvédelem változóival. A magyar vállalatok az outsourcingot valószínúleg vevőszolgálati szituációkra, termékfejlesztésre, kapacitások menedzselésére, a költségek és átfutási idők csök-
\end{abstract} kentésére is előszeretettel használják.

\section{A felhasznált termelésmenedzsment-eszközök (IMSS-mintában 1-5 skála átlagok, versenyképesség mintában igen/nem, a programot választók aránya)}

\begin{tabular}{|c|c|c|c|}
\hline Felhasznált eszközök ${ }^{1}$ & $\begin{array}{l}\text { IMSS } \\
\text { EU }\end{array}$ & $\begin{array}{c}\text { IMSS } \\
\mathrm{Hu}\end{array}$ & VK \\
\hline $\begin{array}{l}\text { Gyártókapacitás növelése (pl. új gépek beszerzése, új emberek } \\
\text { felvétele, új létesítmények építése stb.) }\end{array}$ & 3,27 & 3,41 & 0,46 \\
\hline $\begin{array}{l}\text { Információs és kommunikációs technológiák és/vagy ERP } \\
\text { szoftver bevezetése** }\end{array}$ & 3,26 & 2,78 & 0,34 \\
\hline $\begin{array}{l}\text { Programok a környezetvédelem és az emberek biztonsága és } \\
\text { egészsége érdekében }\end{array}$ & 3,25 & 3,34 & 0,56 \\
\hline $\begin{array}{l}\text { Gyártóberendezések modernizálása az iparági standardot eléró } \\
\text { vagy azt meghaladó szintre }\end{array}$ & 3,21 & 3,35 & 0,54 \\
\hline $\begin{array}{l}\text { Gyártási/szolgáltatási folyamatok és berendezés átstrukturálása a } \\
\text { folyamatfókusz és áramvonalasítás érdekében (pl. sejtszerú elren- } \\
\text { dezés) }\end{array}$ & 3,06 & 2,82 & 0,32 \\
\hline $\begin{array}{l}\text { Minőségjavítási és ellenôrzési programok (pl. TQM, 6szigma } \\
\text { projektek, minôségi körök)*** }\end{array}$ & $\mathbf{3 , 0 2}$ & $\mathbf{3 , 4 6}$ & 0,59 \\
\hline $\begin{array}{l}\text { Delegáció szintjének és a munkaerố tudásszintjének növelése ér- } \\
\text { dekében indított programok (pl. felhatalmazás, képzés, fejlesztô- } \\
\text { vagy autonóm csoportok) }\end{array}$ & 2,93 & 2,88 & 0,41 \\
\hline $\begin{array}{l}\text { Termékfejlesztési folyamat fejlesztését és gyorsítását célzó } \\
\text { programok (pl. platformtervezés, termékmodularizáció, al- } \\
\text { katrész-szabványosítás, párhuzamos fejlesztés, QFD)*** }\end{array}$ & $\mathbf{2 , 8 7}$ & 2,15 & 0,38 \\
\hline $\begin{array}{l}\text { Az ellátási stratégia újragondolása és átstrukturálása az ellátási } \\
\text { portfólió megszervezése és menedzsmentje }\end{array}$ & 2,83 & 2,59 & 0,15 \\
\hline $\begin{array}{l}\text { Programok a húzásos termelés bevezetésére (pl. sorozatnagyság } \\
\text { és átállítási idő csökkentése, kanban rendszerek használata stb.) }\end{array}$ & 2,72 & 2,69 & 0,24 \\
\hline $\begin{array}{l}\text { Programok a gépek termelékenységének fokozására (pl. TPM- } \\
\text { programok) }\end{array}$ & 2,58 & 2,70 & 0,32 \\
\hline Programok a gyártási folyamatok automatizálására & 2,51 & 2,30 & 0,43 \\
\hline $\begin{array}{l}\text { Koncentrálás az alaptevékenységekre, támogató folyamatok } \\
\text { és tevékenységek outsourcingja (pl. készletgazdálkodás, kar- } \\
\text { bantartás, anyagkezelés)*** }\end{array}$ & 2,47 & 2,95 & 0,57 \\
\hline $\begin{array}{l}\text { A vállalat újraszervezése az e-kereskedelem és/vagy e-business } \\
\text { konfigurációk irányába }\end{array}$ & 1,90 & 1,88 & 0,17 \\
\hline
\end{tabular}

1 A * szignifikáns különbséget mutat az IMSS-felmérés magyar és európai része között. $* \mathrm{p}<0,1, * * \mathrm{p}<0,05, * * * \mathrm{p}<0,01$

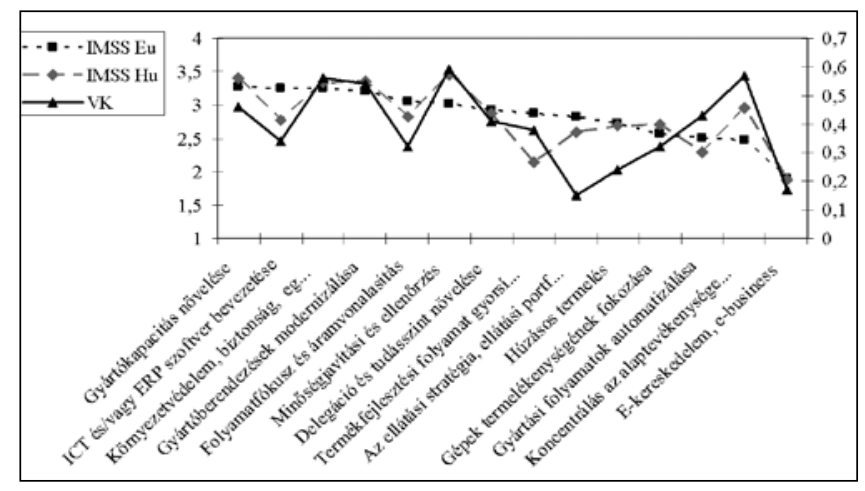

10. táblázat

A 10. táblázathoz tartozó 3. ábra azért különösen érdekes, mert jól mutatja a magyar vállalatok hasonló viselkedését a két mintában, a különböző skálák ellenére. A bal oldali skála az IMSS értékeket, a jobb oldali skála a Versenyképesség-kutatás eredményeit mutatja. Ha jól megnézzük a két magyar adatsort, a görbék alakja nagyon hasonló. A Versenyképesség-minta minden olyan különbséget megerôsít, amit az IMSS-mintában találtunk. Ezeken kívül a folyamatfókusz, az ellátási lánc és a húzásos termelés kap kisebb, az automatizálás viszont nagyobb figyelmet a Versenyképesség-kutatás szereplői között. Ha ezt összevetjük azzal, hogy Laugen et al. (2005) szerint a folyamatfókusz és a húzásos termelés azon termelési programok közé tartoznak, amelyek a leginkább hozzájárulnak a vállalati jövedelmezôséghez, és a gyártási automatizálásnak nincs az eredményességre érzékelhető hatása, akkor ez nem fest igazán pozitív képet a magyar gépipar fejlődési kilátásairól. A nálunk érzékelhetően „hajtott” minôségi programok Európa fejlett területein már nem növelik a vállalati profitot, mint 
ahogy a nálunk még mindig alulfejlettnek tekinthetô információkommunikációs technológiák korszaka is lecsengett. Az eredmények tehát mindenképpen fáziskésésre utalnak.

Lássuk ezek után a termelési technológiákat. Az eredményeket a 11. táblázat mutatja.

11. táblázat

Termelési technológiák alkalmazása (IMSS-mintában

1-5 skála átlagok, Versenyképesség-mintában igen/nem, a programot választók aránya)

\begin{tabular}{|l|c|c|c|}
\hline \multicolumn{1}{|c|}{ Felhasznált technológiák $^{\mathbf{1}}$} & $\begin{array}{c}\text { IMSS } \\
\text { Eu }\end{array}$ & $\begin{array}{c}\text { IMSS } \\
\text { Hu }\end{array}$ & VK \\
\hline $\begin{array}{l}\text { Számítógéppel támogatott terve- } \\
\text { zés (CAD) }\end{array}$ & 3,73 & 3,47 & 0,73 \\
\hline $\begin{array}{l}\text { Automatizált szerszámcsere } \\
\text { és töltés/ürítés* }\end{array}$ & $\mathbf{3 , 3 0}$ & $\mathbf{1 , 9 2}$ & 0,27 \\
\hline CNC/DNC technológia & 2,63 & 2,39 & 0,57 \\
\hline Különálló gépek & 2,78 & 3,01 & 0,73 \\
\hline $\begin{array}{l}\text { Számítógéppel támogatott } \\
\text { gyártás (CAM)*** }\end{array}$ & $\mathbf{2 , 5 9}$ & $\mathbf{1 , 8 9}$ & 0,51 \\
\hline $\begin{array}{l}\text { Számítógéppel támogatott } \\
\text { minóségell./nyomonkövetés* }\end{array}$ & $\mathbf{2 , 5 3}$ & $\mathbf{2 , 9 1}$ & 0,49 \\
\hline Megmunkáló központok & 2,52 & 2,18 & 0,46 \\
\hline $\begin{array}{l}\text { Rugalmas gyártórendszerek } \\
\text { (FMS) }\end{array}$ & 2,14 & 2,14 & 0,14 \\
\hline $\begin{array}{l}\text { Automata raktározási } \\
\text { és elérési rendszer (AS/RS)* }\end{array}$ & $\mathbf{1 , 5 5}$ & $\mathbf{1 , 2 8}$ & 0,11 \\
\hline $\begin{array}{l}\text { LAN/WAN/Intranet/közös } \\
\text { adatbázisok*** }\end{array}$ & $\mathbf{3 , 2 5}$ & $\mathbf{2 , 3 8}$ & - \\
\hline
\end{tabular}

1 A * szignifikáns különbséget mutat az IMSS-felmérés magyar és európai része között.

${ }^{*} \mathrm{p}<0,1, * * \mathrm{p}<0,05, * * * \mathrm{p}<0,01$

Jelentôs lemaradást tükröz a 11. táblázat. Egyedül a számítógéppel támogatott minőség terén van a magyar vállalatoknak némi elônyük, minden egyéb szignifikáns eltérést mutató technológiai tényezóben az európai vállalatok viszik a prímet. Mindenképpen vizsgálni kellene késóbb, hogy mi az oka a magyar vállalatok sokkal intenzívebb minőségorientáltságának. Hiszen ez megjelent a célokban, a felhasznált akcióprogramokban és a technológia terén is. Valószínúleg nem arról van szó, hogy Magyarországon sokkal erósebb a minőségtudatosság, mint máshol Európában. Nagyobb a valószínúsége, hogy az ország nyitottságának a növekedésével, és ezáltal az exporthányad emelkedésével már nem lehet silány minôséget értékesíteni. A silány minőség csapdáját a vállalatok valószínúleg minőségellenőrzéssel és ún. bolondbiztos (fale-safe)
4. ábra

Termelési technológiák alkalmazása grafikusan

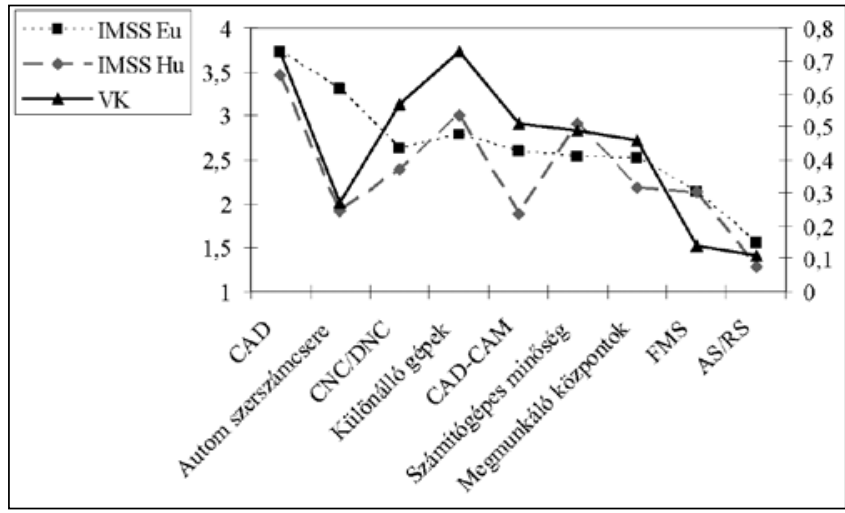

technológiák alkalmazásával igyekeznek elkerülni. A két magyar görbe íve (4. ábra) megint nagyon hasonló, talán a CAD-CAM integrált rendszerek alkalmazása az egyetlen, ami megtöri a sort.

\section{A teljesítmény változása}

A termelési teljesítmény változásának dinamikája a legtöbb dimenzióban hasonló nagyságrendú ( $l d .12$. táblázat és 5. ábra). Minden szempontból előrelépésrôl számolnak be a vállalatok, minden felmérésben és mintában hármasnál magasabbak az átlagok (az 1-5 skálán a 3-as érték mutatja azt, hogy nem történt változás). Ugyanakkor dinamikusnak sem nevezhetố a vál-

12. táblázat

Az elmúlt 3-4 év teljesítményének változása (1 - sokat romlott, 3 - nem változott, 5 - sokat javult)

\begin{tabular}{|l|c|c|c|}
\hline \multicolumn{1}{|c|}{ Teljesítmény-mutatók ${ }^{\mathbf{1}}$} & $\begin{array}{c}\text { IMSS } \\
\text { EU }\end{array}$ & $\begin{array}{c}\text { IMSS } \\
\text { Hu }\end{array}$ & VK \\
\hline Vevószolgálat & 3,70 & 3,67 & 3,36 \\
\hline $\begin{array}{l}\text { Fogyasztók által észlelt } \\
\text { minôség**** }\end{array}$ & 3,69 & 3,95 & 3,79 \\
\hline $\begin{array}{l}\text { Rendelésteljesítés } \\
\text { pontossága*** }\end{array}$ & 3,59 & 3,93 & 3,56 \\
\hline Termelési átfutási idó** & 3,59 & 3,82 & 3,49 \\
\hline Rendelésteljesítési idóo*** & 3,58 & 3,91 & 3,65 \\
\hline $\begin{array}{l}\text { Közvetlen termelési/szolgáltatási } \\
\text { munkaráfordítás }\end{array}$ & 3,57 & 3,71 & 3,53 \\
\hline Kapacitáskihasználás & 3,51 & 3,64 & 3,56 \\
\hline $\begin{array}{l}\text { Új termék-fejlesztés/termékterv- } \\
\text { változtatás idóigénye }\end{array}$ & 3,47 & 3,51 & 3,22 \\
\hline Készletforgás & 3,41 & 3,46 & 3,44 \\
\hline
\end{tabular}

A * szignifikáns különbséget mutat az IMSS-felmérés magyar és európai része között.

${ }^{*} \mathrm{p}<0,1, * * \mathrm{p}<0,05, * * * \mathrm{p}<0,01$ 
tozás, hiszen egyetlen átlag sem került négyes fölé. Az IMSS-felmérésben a magyar vállalatok felzárkózása, dinamikusabb fejlődése figyelhető meg a minőség, a rendelésteljesítési pontosság és a mindennapi múködés időtényezői terén. A Versenyképesség-kutatással öszszevetve viszont mintha a magyar vállalatok teljesítményének alakulása inkább az európai vállalatokéhoz lenne hasonló. Lényeges eltérés a vevôszolgálat és a termékfejlesztés terén tapasztalható a magyar vállalatok rovására. Ez két olyan neuralgikus terület, amely több mint egy évtizede a magyar gazdaság elmaradottságát mutatja. Érdekes, hogy az IMSS magyar adatok nem támasztják alá ezt az állítást, szinte hajszálra beleillenek e dimenziók mentén a nemzetközi mintába.

5. ábra

\section{Teljesítmény-változás grafikusan}

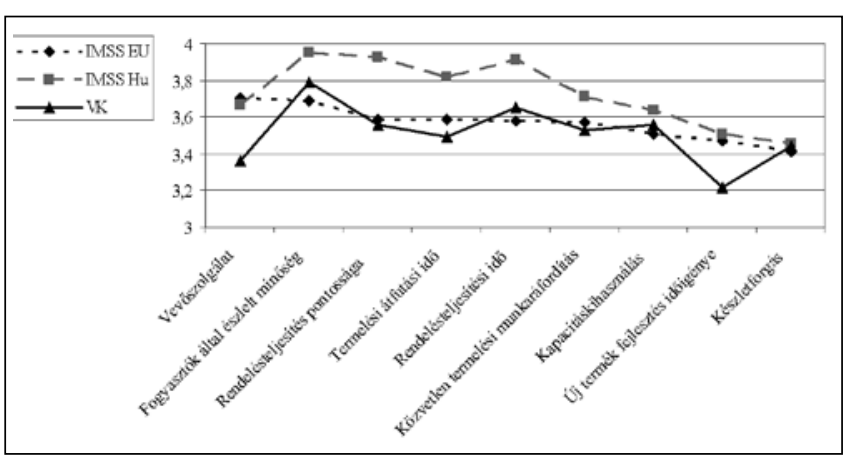

Az IMSS-kutatással való összevetés fö eredményei

$\mathrm{Az}$ elemzéseket vizsgálva újfent megállapítható, hogy termelési téren még mindig nem sikerült felzárkóznunk az európai mezőnyhöz. Vannak azonban pozitív jelek, például, hogy vállalataink gôzerővel dolgoznak a minőség biztosítása érdekében. Meglepő, hogy e célból inkább a technológia lehetôségeit használják ki, pl. talán ezért intenzívebb a számítógépes minőség-ellenôrzés és nyomon követés használata. Ez a tény azt sugallja, hogy elképzelhetô, hogy a magyar munkaerő minőségi szemlélete még nem érte el az európai színvonalat. Ezért a szükséges, Európában elvárt szintet (ami magasabb, mint Közép-Kelet-Európában, de magasabb az amerikai és japán elvárásoknál is, ld. Brouthers, 2000) a technológia segítségével igyekeznek vállalataink biztosítani. További pozitívum, hogy érzékelik a vállalatok a verseny nyomását, tudják, hogy milyen irányba kell tartaniuk. A termelési célok terén ez úgy jelentkezik, hogy ma már mindenhol egyszerre kell jónak lenniük, minden nagyon fontos. Lemaradásuk miatt ezért a magyar vállalatok többfrontos harcot folytatnak, így a prioritások eltúnnek, ami stratégiai szempontból már nem biztos, hogy jó. Európai társaik eljutottak arra a szintre, hogy pl. a gyártási minóséget vagy a rendelés- teljesítés megbízhatóságát már nem tekintik elsôdleges prioritásúnak. Ez a szempont képesítő kritériummá vált náluk (Hill, 1993), ma már a rugalmasság és a folyamatos megújulás szempontjait helyezik előtérbe. Termelési teljesítmény terén tekintve ugyanezeket a folyamatokat, a Nyugat-Európában képesító kritériummá vált szempontokban (minőség, megbízhatóság) gyorsabb fejlődést produkáltak a magyar vállalatok. Ez egyrészt alátámasztja az állítást, miszerint itt már nincs olyan sok tennivaló nyugati társainknál, viszont van behoznivaló idehaza; másrészt mutatja a felzárkózás dinamikáját. A pozitív eredmények mellett ne feledkezzünk el a negatívokról sem. Sajnos van egy-két olyan terület, ahol nyugati társaink gyorsabban fejlődnek nálunk. Az ITháttér biztositása és a termékfejlesztés modern módszereinek alkalmazása (vagy egyáltalán a termékfejlesztés intenzitása) továbbra is neuralgikus területei a magyar vállalatoknak. Ehhez csatlakozni látszik a folyamatszemlélet és a húzásos termelés kérdésköre, amelyek nyugaton ma a versenyképesség elsődleges letéteményesei (Laugen, 2005), nálunk viszont még kevés vállalat jutott el ezeken a területeken a megfelelô szintre, és még mozgolódás sem nagyon látszik.

\section{Összefoglalás}

Az IMSS-kutatással való összevetés és a világszínvonalú termelés vizsgálata egyaránt azt mutatja, hogy termelési téren még sok behoznivalója van a Magyarországon múködő vállalatoknak. Egyáltalán nem bztató, hogy vállalataink többsége a ,nem jutnak messzire” kategóriába került a világszínvonalú termelés kritériumai szerint. Ezt a helyet egyébként abszolút alátámasztja az IMSS európai vállalataival való összevetés. Az alkalmazott termelési programok terén - a minôségre irányuló akcióprogramok használatának kivételével - lemaradásban vagyunk, még ha a különbség nem is mindig szignifikáns. Ugyanakkor a fejlődés dinamikáját tekintve nem látszik lényeges különbség a magyar és az európai eredményesség között.

A lemaradó vállalati csoportba nagyobb valószínúséggel kerülnek kis- és közepes vállalatok, amelyek magyar tulajdonban vannak és vállalati teljesítményük is hagy kívánnivalót hagy maga után. A globalizáció hatásai, nevezetesen a gazdaságossági kérdésekben is szélesedő különbségek tehát egyértelmúen kimutathatóak: a multinacionális leányvállalatok magasabb múködési színvonala, a jobb tốkeellátottság, a standard és központilag fejlesztett szervezet és a kapcsolódó folyamatok találja szembe magát egy szemléletében még nem teljesen átalakult, igyekvő, de tókehiányos kis- és középvállalati szektorral. 


\section{Felhasznált irodalom}

Ballou, R. H. - Gilbert, S. M. - Mukherjee, A. (2000), New managerial challenges from supply chain opportunities, Industrial Marketing Management, Vol. 29, pp. 7-18

Brouthers, L. E. (2000): The influence of Triad nations' environments on price-quality product strategies and MNC performance, Journal of International Business Studies, Vol. 31. No. 1. pp 39-63

Chikán A. - Czakó E. - Demeter K. szerk. (1996): Vállalataink eróltetett (át)menetben, Gyorsjelentés a „Versenyben a világgal" kutatási program kérdőíves felméréséról, BKÁE, Vállalatgazdaságtan Tanszék

Chikán A. - Czakó E. - Zoltayné Paprika Z. szerk. (2004): Fókuszban a verseny, Gyorsjelentés a 2004. évi kérdőíves felmérés eredményeiról, Budapesti Corvinus Egyetem, Vállalatgazdaságtan Tanszék, Versenyképesség Kutató Központ

Collins, R. - Cordon. C. - Julien, D. (1996): Lessons from the 'Made in Switzerland' study: what makes a worldclass manufacturer? European Management Journal, Vol. 14, No. 6, pp. 576-589

Czakó E. - Wimmer Á. - Zoltayné Paprika Z. szerk. (1999): Arccal a piac felé, Gyorsjelentés az 1999. évi kérdőíves felmérés eredményeiról, BKÁE, Vállalatgazdaságtan Tanszék, Versenyképesség Kutató Központ

Demeter Krisztina (2001): Termelés Magyarországon az ezredfordulón, Vezetéstudomány, 2001. feb., 24-33. old.

Demeter Krisztina (1996): Manufacturing strategy in Hungary and in Europe - Are we on the right track? Paper presented at the 9th International Symposium on Inventories, 1996, Budapest, Kézirat

Flynn, B. B. - Schroeder, R. G. - Flynn, E. J. (1999): World class manufacturing: an investigation of Hayes and Wheelwright's foundation, Journal of Operations Management, Vol. 17, pp. 249-269

Frohlich, M. T. - Westbrook, R. (2001): Arcs of integration: an international study of supply chain strategies, Journal of Operations Management, Vol. 19. 2001, pp. $185-200$

Giffi, C. - Roth, A. - Seal, G. M. (1990): Competing in World Class Manufacturing: America's 21st Century Challenge, Business One Irwin, Homewood, IL.

Hayes, R. H. - Wheelwright, S. C. (1984): Restoring Our Competitive Edge: Competing Through Manufacturing, Wiley, New York

Hill, T. (1993): Manufacturing strategy, 2nd edition, MacMillan, London

Laugen, B. T. - Acur, N. - Boer, H. - Frick, J. (2005): Best manufacturing practices - What do best-performing companies do?, International Journal of Operations \& Production Management, Vol. 25., No. 2.

Narasimhan, R. - Kim, S. W. (2001): Information System Utilization Strategy for Supply Chain Integration; Journal of Business Logistics, Vol. 22, No. 2
Prabhu, V. - Yarrow, D. - Gordon-Hart, G. (2000): Best practice and performance within Northeast manufacturing, Total Quality Management, Vol. 11, No. 1, pp. 113-122

Rosenzweig, E. D. - Roth, A. V. - Dean Jr., J. W. (2003): The influence of an integration strategy on competitive capabilities and business performance: an exploratory study of consumer products manufacturers, Journal of Operations Management, Vol. 21, pp. 437-456

Scannel, T. V. - Vickery, S. K. - Dröge, C. L. (2000): Upstream supply chain management and competitive performance in the automotive supply industry, Journal of Business Logistics, Vol. 21, No. 1, pp. 23-48

Schonberger, R. J. (1986): World Class Manufacturing: The Next Decade, Free Press, New York

Senter, R. - Flynn, M. S. (1999): Changing interorganizational patterns in the North American automotive supply chain, Applied Behavioral Science Review, Vol. 7, No. 1, pp. 59-80

Swinehart, K. D. - Miller, P. E. - Hiranyavasit, C (2002): World Class Manufacturing: Strategies for Continuous Improvement, Business Forum, Vol. 25. No. 1-2, pp. 19-27

Vickery, S. K. - Jayaram, J. - Droge, C. - Calantone, R. (2003): The effects of an integrative supply chain strategy on customer service and financial performance: an analysis of direct versus indirect relationships, Journal of Operations Management, Vol. 21, pp. 523-539

Voss, C. - Blackmon, K. (1996): The impact of national and parent company origin on world-class manufacturing, International Journal of Operations and Production Management, Vol. 16, No. 11, pp. 98-115

Voss, C. - Blackmon, K. - Hanson, B. - Oak, B. (1995): The competitiveness of European manufacturing - A four country study, Business Strategy Review, Spring, Vol. 6, No. 1, pp. 1-25.

Wimmer, Á. - Csesznák A. (2005): Vállalati jellemzók és öszszefüggéseik az EU-csatlakozás idején, A ,Versenyben a világgal 2004-2005" kutatási programban résztvevő vállalatok jellemzése, A versenyben a világgal 20042005 - Gazdasági versenyképességünk vállalati nézôpontból címú kutatás 3. sz. múhelytanulmánya

\section{Lábjegyzet}

\begin{abstract}
Mivel a Versenyképesség-kutatásban volt olyan kérdés is, ahol - többek között - a termelési teljesítmények versenytársakhoz viszonyított értékére is rákérdeztünk (pl. határozza meg 1-5 skálán, hogy a rendelésteljesítési idő hogyan alakul a legerósebb versenytárshoz viszonyítva), ezért ezekre is elvégeztük az elemzést, és nagyon hasonló eredményekre jutottunk. A vállalatok $75 \%$-a ugyanabba a kategóriába került. Azért választottuk mégis a teljesítmény-változást, mert arra ugyanaz a személy válaszolt, mint a többi vizsgált kérdésre.
\end{abstract}

